\title{
Comment: the coming tornado?
}

Ray McAleese

Centre for Combined Studies, Heriot-Watt University. Email: rmcaleese@hw.ac.uk

An extended review of John S. Daniel's Mega-Universities and the Knowledge Media: Technology Strategies for Higher Education (London: Kogan Page, 1996; 212 pages, ISBN: 0-7494-2119-3).

I will start with a declaration of interest and prejudice. I have been for some thirty years a 'learning technologist', or what used to be unfashionably called an 'educational technologist'. I have observed and read books, chapters and papers by John Daniel, the author of this work, for about twenty years, since his days in Concordia University, Montreal. Professor Daniel is without peer as a judge of continuing, open and distance education. As Vice-Chancellor of the Open University, he has seen his institution grow to a leading position in the UK open-learning market with hundreds of courses offered under its inimitable course-design system. He has ensured that the Open University is a beacon of what is best in innovative teaching and programme delivery. He has steered an adept course, gaining widespread international approval for the prototypical University of the Air. His views are canvassed by the Great and the Good. One can discern his hand in the recent Dearing (1997) recommendations.

Why, then, do I feel uncomfortable with this book? I started this review almost a year ago, just in time for the publication of the Dearing Report in the summer of 1997. I thought, as I read more and more of the book, that I wanted to say Yes. But I also wanted to argue. I wanted to contest, to say: 'It's not like that. I don't like the way you describe what you claim we do.'

The thrust of Daniel's argument is that there is a global crisis in the old world of higher education. Universities have a window of opportunity to take advantage of developments in information and communications technology. Knowledge media have become a commodity that is attractive to entrepreneurs and students alike. Sufficient is known of competitive advantage between organizations to draw up strategic guidelines for innovative institutional plans. Further, there are tried and tested implementations strategies for 
technology-based teaching drawn from organizational change and development. All these developments will allow the old-world universities to become, like the Open University, successful mega-universities. The argument is simple. The evidence is well documented (the book's origin is in a doctoral dissertation written during a sabbatical leave). The writing is easy.

So what, again, is it that makes this book uncomfortable reading for me? If one takes Daniel's logical analysis of competitive advantage, the reason is soon apparent. He starts his argument with the premise that rational economic analysis is appropriate for the output of universities. He asserts that students are outputs and the buyer is the State. Further, and by implication, students themselves buy universities as consumers. Some (for example, Hobbs, 1998) have doubted if such a rational cost-sensitive demand exists, and if it does, how it is characterized. Interestingly, this recursive consumerism is currently exhibiting a decline in demand because the price of the product has just been gazumped by the Government. The introduction of the $£ 1,000$ fee is highlighting the complex supply and demand system that operates. This effect suggests that universities may have a product ('knowledge') and that students will value and pay for it, just as they would for any other commodity. Daniel's market-based economic analysis goes on to suggest that students, in turn, acquire 'skills' through just-in-time delivery of courses in what Tom King et al. in another irritating book, so inelegantly call 'learn-places' (Ford et al, 1996; see reviews of this book in $A L T-J, 5(2), 64-74)$. The fact is that student demand has crossed a cusp. Perhaps there really are market forces at work. Not only is there a demographic-led increase, but perhaps also a rational market-led decrease. In 1998, the most recent figures from UCAS suggest that there is a definite decline in the number of applicants for university places in UK. Daniel is able to conclude that universities should focus on five core activities, namely: 'inbound logistics, operations, outbound logistics, marketing and sales' (p.73).

The issue I sense here is the use of a commodity-oriented framework that seems and feels wrong for my understanding of a university. My orientation to universities is more in keeping with Bruce Truscot's (1943) much maligned Red Brick University, or the collegiality of the pre-Robbins community of scholars, rather than the consumerism of the modern 'mega-university' system. To me, the language of description and analysis seems to ignore what universities do best. I feel that universities should concentrate on educating young people. It is as simple as that. Universities should provide a scholarly and rigorous framework for the creation and adoption of scientific knowledge. Universities, after all, consist of scholar-teachers who engage with learners in a shared activity - teaching and learning - based on post-Newman scholarship. Now, it is logical and feasible to analyse any system using a different framework. Such a device is often used by social scientists who suggest, for example, an epidemiological model for the adoption of new ideas. It is as if ideas propagate, disseminate and are curtailed in a way that is similar to the growth of a biological epidemic. They. use this socio-medical framework to suggest interesting new insights. However, unlike my reading of Daniel, they do not go on from a useful analytical framework to a deterministic projection of how things should be. Normative determinism, based on an interesting but inappropriate framework is a characteristic I sense in Daniel's book. The analysis of the 'value chain'-logical and appropriate to such as the electronics industry - seems a wholly inappropriate way to understand how universities can make the 
most of technological opportunities to facilitate learning and scholarship. It does not seem like that to me.

The reality of being a student or a teacher in higher education may of course be different from the noble aspirations I allude to above. Teaching is a job just like many others in a service industry. There are clients who have expectations, and the teachers meet these expectations in a professional way. They share their expertise through well-tried teaching methods, while at the same time keeping abreast of their subject discipline and contributing to the success of their institution through research and consultancy. Likewise, students have a need to acquire paper qualifications that certify them as being competent and employable. Their 'graduateness', while comprising both transferable skills and subject-based skills, is judged by their ability to perform traditional tests of recall, evaluation and communication. And the reality, as seen from the shop floor, is of many teaching staff and researchers disaffected with the inexorable drive to research output and efficiency. The workforce is under-skilled and sometimes untrained. Its ability to make the most of communications and information technology hangs on initiatives that aim to disseminate best practice, and on painfully short induction courses to the complexities of 'teaching over the Web' and 'automatic assessment using self-marked tests'. Most teachers want to help learners understand what they need in order to be successful, not to acquire a new set of professional skills for which they will receive no direct reward.

The experience of being a student is no less confusing. Many students - up to a third in some instances - come to university with almost no communications or IT skills. They have experienced traditional or neo-traditional teaching methods in schools, and their only ability to reflect on their competencies has been in preparing a short CV for a summer job. When they are invited to take responsibility for their own learning and to seek out information for themselves in order to satisfy the requirements of distant teachers, they cry for help and consume a disproportionate amount of tutoring time. Often, the teacher and the taught are both on a voyage of discovery into the complexities of a computersupported collaborative learning environment. The reality is that while there is much to be said for communications and information technology in higher education, there are few listening and few with the minimum set of skills to achieve 'take-off'. If this were not true, why should the Funding Councils support initiatives such as TLTP and LTDI? There is a crisis with under-skilled staff and students. There are solutions to problems that do not exist and no solutions for problems that do exist. A reasonable view might be to concentrate our efforts on a better understanding of the process of learning - using the existing technologies - before starting on a head-long rush to re-skill, re-learn and reorganize. There is a respectable argument that suggests: Do what you do best well, before your do new things. I only wish John Daniel had placed more weight in Chapters 2 and 3 on the book by his colleague Diana Laurillard (Laurillard, 1993). When she asked what students bring to learning, and examined the 'complexity of coming to know', she touched on the essential ingredient for a successful higher-education business: an understanding of the customer.

In a chapter entitled Making Technology Attractive (Chapter 0), Daniel uses Moore's (1995) 'technology life-cycle' to argue the case for capitalizing on technology to 'dominate the niche' (p. 90). Daniel asserts: 'The organisation that develops whole products successfully in a series of niches may create a tornado as the mass market takes off' (p. 93). The 
tornado concept - an unstoppable advance through synergistic alliances - allows, as Daniel paraphrases Moore, 'large numbers of customers to enter the market simultaneously, swamping the supply system and creating a frenzy' (p. 94). The implication is clear for those who wish to see it. Technology is going to support learners and institutions, but only those who move forward using the technology paradigm will survive. Only those institutions who see their competitive advantage being served by buying into distance learning, open systems and communications and information technology will be the real players. It is almost like the tornado that blows the smaller football clubs away when the Premier clubs strike deals with the media to take them to a state of higher turnover and profitability. The comparison between soccer and scholarship is not only close; it offers an opportunity to consider the impact of competitive advantage on those who still enjoy standing on the terraces supporting local heroes.

Now, this is where one can see the full impact of Daniel's' argument. In the real world, technology-supported infra-structures are differentiating between those that are keeping up and those that will have to change or be left behind. The higher-education system is infected with the competitive spirit. Attracting punters (sic) is now an every-day job for each and every one of us. To offer better opportunities to learn through Metropolitan Area Networks; to share applications over distributed systems, and to be a member of a virtual community of learners is what we are told should be attracting more students . John Daniel may be right, but I do not like it. I feel exposed. I may have to change my cost stance. I may have to reflect on what I should do, not what I like doing.

Turning to the core issue, 'knowledge-media', may present an attractive proposition as far as learning technology is concerned. Daniel draws heavily on his well-informed Open University colleagues Diana Laurillard and Mark Eisenstadt. It is Eisenstadt's 'knowledgemedia' that offers such an attractive term in the title of the book. The observed convergence of telecommunications and computing, along with the cognitive and learning sciences, has suggested this term to Eisenstadt. The key assumption by Eisenstadt is the belief that the increased 'bandwidth' of what Dearing was later to call the communications and information technologies, gives rise to qualitative differences in what can be learned and what is learned. Because it is possible to push terabytes out over a network, it is possible now to create new virtual learning environments - so the argument goes. No longer do students have to wait at their modems for a trickle of bytes at 1200 Baud to download the tutor's comments on their assignments. Students can make the most of distant tutors who can see, hear and almost touch the cyber-learners. Of course, there is a lot of sense in this chapter (Chapter 7). Diana Laurillard - who herself made a highly significant contribution to the Dearing Committee and Report - has previously offered a 'conversational framework' for understanding how learning is facilitated. This conversation facilitates the social aspect of learning. Learning, according to Laurillard is discursive, adaptive, interactive and reflective. Her analysis, first widely publicised in $R e$ Thinking University Teaching (Laurillard, 1993) is clearly referred to by Daniel, but I feel he does not make the most of her analysis. Perhaps in a similar way, the conclusions of the MacFarlane Report (1992) paid lip-service to the thorough analysis of Entwistle et al who provided the pedagogy for the report's Intensely Supportive Learning Environments (MacFarlane, 1995). MacFarlane (1992) himself placed a high premium on making learning 'more productive and efficient by harnessing modern technology' (p.13). On a 
larger canvas, Daniel seems to prefer the artefacts that emanate from 'knowledge-media' to the cybernetic negotiation of understandings between teachers and students mediated through communications media. In summary, Daniel concludes: 'Universities need to do considerable development work if they are to derive full advantage from opportunities such as on-line tutoring and the Internet' (p.135). Here, again, I can see the road ahead like the Bill Gates vision. The potential to place the cart (the technology artefacts) before the horse (the instructional technology of Laurillard's 'conversational system') is all too apparent.

So what is it in this book that has made me read it, re-read it, think about it, talk about it, cite it, hate it? It is the logic of Daniel's argument. I fear he is right. I may have been left behind. The world out there that allows me to support my students through my mail system while I write this passage at home. The ability of high-performance workstations to model complex process and allow learners to engage in their own learning process is here now. I suspect the real impact of John Daniel's' book will be that it brings out in each of us - in a cathartic exorcism - the deepest, darkest feeling that we have been dinosaurs in a park, owned and run by the entrepreneurial knowledge-scientists.

This reminds me of the way Barbara Falk, the Grand Lady of Australian staff development in the 1970s, alluded to the role of the successful staff developer as being like 'a professional irritant'. The successful staff developer makes others 'scratch'. It is perhaps Daniel's role in writing this book, from the authority of his long experience, to irritate the rest of us into new ways of seeing the world. If the reader wants to know: how to initiate change; what the new language of innovative teaching is; how to get one over on the next department/college/ system, then this book will be essential reading. If the reader wants to understand what is known about learning and scholarship under communications and information technology, there are pointers galore. If the reader wants to impress the senior-management team with an awareness of the next window of opportunity, this book is required reading. I still want to know more of the 'ethnographic' studies Daniel refers to that explicate the process of learning. I want to know what will happen when the current wave of communications and information technology is superseded by new and as yet unthought of artefacts. I want to know how I am to compete for attention as a learning technologist, without selling cosy scholarly principles to The Grim Technology Reaper. But before I change my name to Faust, I have to acknowledge a debt to Professor Daniel. I journeyed through his book and wriggled on every page. Yet I have now read it cover to cover on three occasions. I feel I will do so again.

For more down-to-earth readers, the book has eight well written chapters, a fascinating set of biographies of existing 'mega-universities' in the Appendix, and a useful bibliography to set them off verifying, corroborating, testing Daniel's assertions. May their journey be interesting.

\section{References}

Dearing et al (1997), Higher Education in the Learning Society: Report of the National Committee of Inquiry into Higher Education, London: HMSO and NCIHE Publications.

Ford, P. et al (1996), Managing Change in Higher Education: A Learning Environment Architecture, London: Open University Press. 
Hobbs, P. (1998), 'An analysis of teaching methods, costs and student preferences', Active Learning, 7, 8-10.

Laurillard, D. (1993) Rethinking University Teaching, London: Routledge.

MacFarlane Report (1992), Teaching and Learning in an Expanding Higher Education System, Committee of Scottish University Principals, ISBN: 0-9519377-1-5.

MacFarlane, A.G.J. (1995) 'Future pattern of teaching and learning' in Schuller, T. (ed), The Changing University?, London: Open University Press.

Moore, G.A. (1995), Inside the Tornado, New York: Harper Business.

Porter, M.E. (1985), Competitive Advantage: Creating and Sustaining Superior Performance, New York: Free Press.

Truscot, B. (1943) [pseudonym of E.A. Peters], Red Brick University, London: Faber \& Faber. 